\title{
初期変位付与型 TMD の同調比の設定 \\ SETTINGS OF TUNING RATIOS OF TUNED MASS DAMPERS WITH INITIAL DISPLACEMENT
}

\author{
吉中 進*, 小鶴桂 太**, 谷口 与史也*** \\ Susumu YOSHINAKA, Keita KOZURU and Yoshiya TANIGUCHI
}

\begin{abstract}
In order to control the transient response more effectively, we propose TMDs (Tuned mass dampers) with initial displacement. In our previous study, we formulated the equation for initial conditions to release initial TMD displacement. By using this equation, the structural response of the first mode with the lowest modal damping is eliminated on a two-degrees-of-freedom model. In this paper, we study the effect of the settings of TMDs tuning ratios on the control performance. And we study the causes focusing on the interrelationship between a main mass and two TMDs on the complex plane and the TMD power flow.
\end{abstract}

Keywords : Vibration control, Tuned mass damper, Initial displacement, Tuning ratio, TM D power flow 振動制御, TMD, 初期変位, 同調比, TMD パワーフロー

\section{1. はじめに}

TMD(Tuned Mass Damper)は, 重錘, ばね, ダンパーで構成され, 構造物に取り付けて共振させることで, 構造物の振動エネルギーを重 錘の運動エネルギーとして吸収し, ダンパーの減衰力によりエネルギ 一を消散するパッシブ型の振動制御手法である ${ }^{1)}$ 。TMD は, 構造物の 1 点の絶対応答量に対して作用する制御手法であり, 空間的な設置自 由度の高さから形状と構造システムが多様で複雑な構造物に対して 適用性が高いと考えられるため本研究では空間構造への適用を主な 目標としているが，重層構造など他の構造物への応用も可能であると 考えている。一方，TMD の制振効果は定常状態を想定したものであ り, 地震動など非定常性の強い外力に対する制振効果は定常外力と比 較して低いことが分かっている 2)。これはパッシブ型の TMD は AMD(Active Mass Damper)のように重錘を強制的に運動させる外部 エネルギーがないため, 安定した振動状態となるまで制振効果が発現 されないためである3)。そこで著者は，TMD にあらかじめ初期変位を 付与し, TMD の制振効果が低い過渡応答初期の効果を向上させるた めに初期変位付与型 TMD を提案した。提案手法は一般的な TMD で は制御が難しい大地震時における応答制御を目標としている。

著者は，既報 4)でインパルス外力が作用する場合の初期変位付与型 TMD の設計式を提案した。提案式は，TMD の減衰比をある特定の值
よりも大きくすると TMD 減衰比とモード滅衰比の関係が変化するこ とに着目し, インパルス外力の作用直後, 寸なわち応答速度極大の時 刻で初期変位を解放する条件で，TMD 初期変位の向きと大きさを適 切に設定することにより低減衰モードの忘答を消去し，高減衰モード のみで振動させることができる現象に基づいている 5)。次に著者は, 自由振動の理論解より初期変位解放条件式を導き, 高減衰モードのみ で振動する構造物の初期条件に関して, TMD が 1 個の場合は初期変 位と初期速度の関係が固定されているが，同調比の異なる 2 個以上の TMD を用いることにより, 初期変位と初期速度に関して初期変位解 放条件式を満足する任意の值を選択することが可能であることを示 した 6)。既報 7)では, 空間構造のように複数の振動モードが励起しや すい構造物においても提案式が有効であることを示した。次に小型の 初期変位付与型 TMD 模型を試作してアーチモデル打撃試験を実施し て初期変位付与型 TMD の制振効果と提案した設計式の有効性を実験 的に検証し，初期変位の解放時刻と大きさが制振効果に与える影響を 解析的に確認した 8)。インパルス外力以外には，既報 9)で調和地動加 振を受けた場合の制振効果について，ある一定時間（制振効果時間） の経過後は初期变位の無い通常の TMD として作用寸ることを確認し た。さらに既報 10)で地震時における本手法の制振効果が, 通常の TMD と比較して，特に最大応答抑制効果に優れることを確認した。

\footnotetext{
本論文は，文献 15），16）の内容に加筆・修正したものである。 大阪市立大学大学院工学研究科都市系専攻 准教授·工博

** 大阪市立大学大学院工学研究科都市系専攻 大学院生 . 工修

*** 大阪市立大学大学院工学研究科都市系専攻 教授. 工博
}

Assoc. Prof., Urban Engineering, Faculty of Engineering, Osaka City University, Dr. Eng.

Grad. Student, Faculty of Engineering, Osaka City University, M. Eng.

Prof., Urban Engineering, Faculty of Engineering, Osaka City University, Dr. Eng. 
既往の研究 9),10)で述べたように, 初期変位付与型 TMD は地震時に おける最大応答抑制効果に優れるが, 初期変位解放後ある一定時間経 過後は通常の TMD としての効果の夕有する。よって長時間の地震動 に対して効果を発現するためには複数回の初期変位付与・解放動作が 必要となる。そのため実際の構造物への適用においては, 常時効果を 有する通常の TMD と組み合わせ, 通常の TMD では対応できない領 域で初期変位付与型 TMD を用いることを考えている。初期変位付与 型 TMD は一般のアクティブ制振と異なり, 必要な外部エネルギーは 基本的に数回の初期変位付与時のみであり, 将来的にはエネルギー回 生システムの利用などにより外部エネルギーの無い自立したシステ ムの構築を目指している。

これまで著者は主として TMD に初期変位を付与することで低減衰 モードの応答が消去可能となる現象に着目して研究を進めてきた。し かし TMD の個数が 2 個以上になると, 低減衰モードを消去した残り の複数の高減衰モード全体の応答で制振効果を評価する必要がある。 そこで本論文では, 最初に, 2 個の TMD の同調比をパラメータとし て, 同調比の設定が主振動系の応答と TMD 初期変位の大きさに与え る影響を検討する。次に検討結果に関して, 主振動系と 2 個の TMD の相対的な関係に着目し, 初期条件を複素平面上で固有モードベクト ルに分解する方法, TMD の付加減衰効果を表す指標である TMD power flow を用いる方法の二つの方法により考察する。なお, 初期変 位付与型 TMD の目標は過渡応答初期の制振効果を向上させることで あるから, 本論文では自由振動のみを取り扱い, TMD の初期変位は 振動開始時刻に解放した。また本論文では, 初期変位付与型 TMD に より応答を消去する最も減衰の低いモードを 1 次モードとし, それ以 外のモードについてはモード減衰比の小さい方から順番にモード次 数を割り当てる。

\section{2. 初期変位付与型 TMD の設計式と初期変位解放条件式}

既往の研究 4),6)で提案した設計式と初期変位解放条件式をまとめる。

\section{1 設計パラメータ}

初期変位付与型 TMD の設計パラメータは, Fig.1 に示すように, TMD の重錘の質量 $\mathrm{m}_{\mathrm{T}}$ に対する主振動系（構造物）の等価質量 $\mathrm{M}_{\mathrm{S}}$ の 比である質量比 $\mu$ の他に, (i)同調比 $\gamma$, (ii)減衰比 $\xi_{\mathrm{T}}$, (iii) 初期変位 y(0)である。(i) と(ii)は通常の TMD と共通のパラメータである。

(1)式に示すように, 同調比 $\gamma$ は主振動系の固有円振動数 $\omega_{\mathrm{s}}$ に対す る TMD の固有円振動数 $\omega_{\mathrm{T}}$ の比であり, 減衰比 $\xi_{\mathrm{T}}$ は TMD の臨界減 衰係数に対する TMD の減衰係数 $\mathrm{C}_{\mathrm{T}}$ の比である。

$$
\begin{aligned}
& \mu=\frac{\mathrm{m}_{\mathrm{T}}}{\mathrm{M}_{\mathrm{S}}}, \quad \gamma=\frac{\omega_{\mathrm{T}}}{\omega_{\mathrm{S}}}, \quad \xi_{\mathrm{T}}=\frac{\mathrm{c}_{\mathrm{T}}}{2 \mathrm{~m}_{\mathrm{T}} \omega_{\mathrm{T}}} \\
& \text { (i) Tuning ratio } r \text { restion }
\end{aligned}
$$

Fig. 1 Design parameters of TMD with initial displacement

\section{2 同調比と減衰比の設定}

本研究では, 同調比の設定に自由振動最適化パラメータの設計式で ある(2)式を用いる11。同調比に自由振動最適化パラメータを用いたと
きの TMD の減衰比とモード減衰比, 非減衰固有円振動数比の関係を Fig. 2 に示す。TMD の質量比 $\mu$ は $2.0 \%$ とし, 主振動系の減衰は考慮 していない。 $\omega_{1}$ と $\omega_{2}$ は 1 次と 2 次モードの固有円振動数である。図 中で $\mathrm{A}$ 点が(3)式で示す自由振動最適化パラメータの TMD 減衰比を 用いたときのモーダル減衰比と非減衰固有円振動数比である。

$$
\begin{aligned}
& \gamma_{\mathrm{opt}}=\frac{1}{1+\mu} \\
& \left(\xi_{\mathrm{T}}\right)_{\mathrm{opt}}=\sqrt{\frac{\mu}{1+\mu}}
\end{aligned}
$$

図に示すように, A 点より小さい TMD 減衰比の領域では, 2 つの モードの減衰比は等しく, 固有振動数は異なる。逆に $\mathrm{A}$ 点より大きい TMD 減衰比の領域では, モード減衰比は異なり, 固有振動数は等し い。特に A 点よりも大きい領域では Fig.2(a)に示すように，1 次モー ド減衰比 $\xi_{1}$ と比較して 2 次モード減衰比 $\xi_{2}$ が非常に大きくなり, A 点の TMD 減衰比を境に振動性状が大きく変化する。本研究では, (i) 過渡応答と共振応答の低減効果, (ii)TMD の減衰比の変動に対寸る制 振効果のロバスト性, の 2 点を考慮して, TMD 質量比が 1 ～ $5 \%$ 程度 の範囲における TMD 減衰比として, 以下の(4)式を提案している4)。 Fig.2では B 点と C 点に対応する。

$$
\left(\xi_{\mathrm{T}}\right)_{\mathrm{opt}}=\left(31.25 \times \mu^{2}\right)^{1 / 3}
$$

主振動系に減衰比 $\xi_{\mathrm{S}}$ が存在する場合の最適同調比と最適減衰比は以 下の式で表される4)。

$$
\begin{aligned}
& \gamma_{\mathrm{opt}}=\frac{\xi_{\mathrm{T}}-\xi_{\mathrm{S}}}{(1+\mu) \xi_{\mathrm{T}}-\xi_{\mathrm{S}}} \\
& \left(\xi_{\mathrm{T}}\right)_{\mathrm{opt}}=\left(31.25 \times \mu^{2}\right)^{1 / 3}+\left(\left(\xi_{\mathrm{T}}\right)_{\mathrm{A}^{\prime}}-\left(\xi_{\mathrm{T}}\right)_{\mathrm{A}}\right)
\end{aligned}
$$

(6)式中の第 2 項は, 主振動系に減衰が有る場合と無い場合において, モード減衰比が分岐する点（文献 4)の Fig.15のA 点とA'点）におけ る TMD 減衰比の差である。なお，本論文で 2 個以上の TMD を用い る場合に TMD の減衰比は(6)式で得られた值を用い, 同調比は(5)式を 用いずに検討を行った。

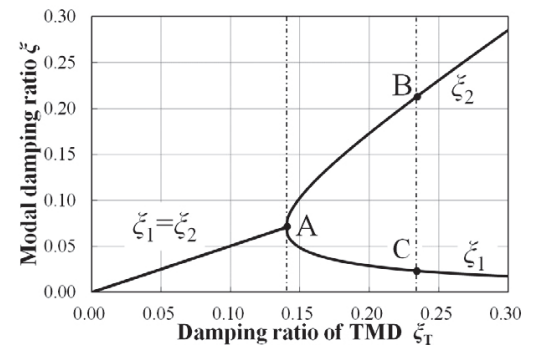

(a) Modal damping ratio

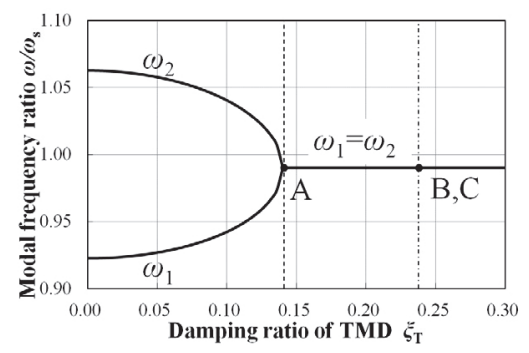

(b) Modal frequency ratio

Fig. 2 Relationships between TMD damping ratio and modal damping ratio and frequency ratio $(\mu=2 \%)$ 


\section{3 初期変位解放条件式}

著者は自由振動応答の理論解 12 )に基づき, 2 次モード単独で振動す る, すなわち 1 次モードの応答が 0 となる Fig.1の主振動系／TMD で 構成される全体系の初期条件として，(7)式の初期変位解放条件式を導 いた ${ }^{6)}$ ここで， $\boldsymbol{\kappa}_{1}$ は 1 次の固有ベクトルである。

$$
\mathbf{\kappa}_{1} \mathbf{a u ̂}(0)=0
$$

速度ベクトルと変位ベクトルの項に分けると以下のようになる。

$$
\left\{\begin{array}{ll}
\lambda_{1} \boldsymbol{\psi}_{1} & \boldsymbol{\psi}_{1}
\end{array}\right\} \mathbf{a}\left\{\begin{array}{l}
\dot{\mathbf{u}}(0) \\
\mathbf{u}(0)
\end{array}\right\}=0
$$

上式で $\lambda_{1}$ は 1 次モードの固有值, $\boldsymbol{\psi}_{1}$ は 1 次モードの固有変位ベクト ルである。マトリクス $\mathbf{a}$ は, 全体系の質量マトリクス $\mathbf{m}$, 減衰マトリ クス cで構成される(9)式の状態マトリクスである。 u( 0 )と $\mathbf{u}(0)$ は初 期変位と初期速度のベクトルである。

$$
a=\left[\begin{array}{ll}
0 & m \\
m & c
\end{array}\right]
$$

（7)式の物理的な意味は，1次の固有ベクトル（モーダル速度，モー ダル変位）と初期速度, 初期変位に関する初期条件ベクトルが, マト リクス $\mathrm{a}$ に関して一般直交性を有することである。一般直交性を有す るとは, 固有ベクトルと初期条件ベクトルが力学的に互いに独立で, エネルギー的に無関係であることを意味する ${ }^{13)}$ 。すなわち，1 次モー ドと力学的に独立で, エネルギー的に無関係な初期条件を与えた場合 に， 1 次モードの応答が 0 となる。既往の研究 6)で述べたように, 一 般粘性減衰における固有ベクトルは複素数となるため, (7)式で得られ る TMD 初期変位も複素数となる。次章で述べるように 2 個以上の TMD を用いることで初期変位を実数にすることが可能となる。

\section{3. 同調比の設定と主振動系の応答, TMD 初期変位の関係}

本章では, 同調比の異なる 2 個の TMD を用いたときに, 同調比の 設定の違いが主振動系の応答と TMD 初期変位の大きさに与える影響 について検討する。

\section{1 初期変位の設定方法}

Fig.3 に示す 3 自由度モデルの自由振動運動方程式は(10)式で表さ れる。 $x_{5}$ は主振動系 (構造物) の絶対変位, $x_{T 1}$ と $x_{T 2}$ は 2 個の TMD の絶対変位である。 $\mathrm{y}_{1}(0), \mathrm{y}_{2}(0)$ は主振動系に対する TMD の初期相 対変位（実際の装置に付与する初期変位）であり区別する。

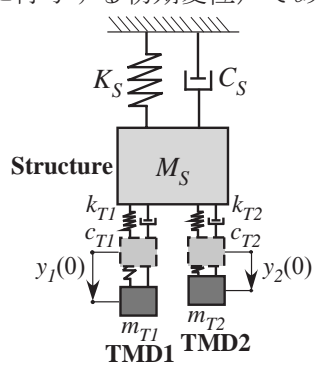

Fig. 3 Analytical model

$$
\begin{gathered}
{\left[\begin{array}{ccc}
\mathrm{M}_{\mathrm{S}} & 0 & 0 \\
0 & \mathrm{~m}_{\mathrm{T} 1} & 0 \\
0 & 0 & \mathrm{~m}_{\mathrm{T} 2}
\end{array}\right]\left\{\begin{array}{l}
\ddot{x}_{\mathrm{S}} \\
\ddot{x}_{\mathrm{T} 1} \\
\ddot{x}_{\mathrm{T} 2}
\end{array}\right\}+\left[\begin{array}{ccc}
\mathrm{C}_{\mathrm{S}}+\mathrm{C}_{\mathrm{T} 1}+\mathrm{C}_{\mathrm{T} 2} & -\mathrm{C}_{\mathrm{T} 1} & -\mathrm{C}_{\mathrm{T} 2} \\
-\mathrm{C}_{\mathrm{T} 1} & \mathrm{C}_{\mathrm{T} 1} & 0 \\
-\mathrm{C}_{\mathrm{T} 2} & 0 & \mathrm{C}_{\mathrm{T} 2}
\end{array}\right]\left\{\begin{array}{l}
\dot{x}_{\mathrm{S}} \\
\dot{\mathrm{X}}_{\mathrm{T} 1} \\
\dot{x}_{\mathrm{T} 2}
\end{array}\right\}} \\
+\left[\begin{array}{ccc}
\mathrm{K}_{\mathrm{S}}+\mathrm{k}_{\mathrm{T} 1}+\mathrm{k}_{\mathrm{T} 2} & -\mathrm{k}_{\mathrm{T} 1} & -\mathrm{k}_{\mathrm{T} 2} \\
-\mathrm{k}_{\mathrm{T} 1} & \mathrm{k}_{\mathrm{T} 1} & 0 \\
-\mathrm{k}_{\mathrm{T} 2} & 0 & \mathrm{k}_{\mathrm{T} 2}
\end{array}\right]\left\{\begin{array}{l}
\mathrm{x}_{\mathrm{S}} \\
\mathrm{X}_{\mathrm{T} 1} \\
\mathrm{X}_{\mathrm{T} 2}
\end{array}\right\}=\left\{\begin{array}{l}
0 \\
0 \\
0
\end{array}\right\}
\end{gathered}
$$

主振動系のパラメータ $\mathrm{M}_{\mathrm{s}}, \mathrm{K}_{\mathrm{s}}, \xi_{\mathrm{s}}$ はそれぞれ $1 \mathrm{~kg}, 100 \mathrm{~N} / \mathrm{m}, 0.02$ と する。 2 個の TMD の合計質量比 $\mu$ は $2 \%$ とし， 2 個の TMD 質量は $0.01 \mathrm{~kg}$ で同じとする。TMD の減衰比は(6)式を用い, 0.2517 とする。 主振動系が初期変位の夕を有する場合に, TMD の初期変位を実数值 とするための初期変位解法条件式の適用方法については, 文献 6 ）の 6. 2 節で述べたが，ここでは主振動系が初期速度と初期変位の両方 を有する場合に拡張して整理する。(8)式で $\left\{\begin{array}{ll}\lambda_{1} \boldsymbol{\psi}_{1} & \boldsymbol{\psi}_{1}\end{array}\right\} \mathbf{a}$ の $1 \times 6$ のベク トルの成分を $\psi_{1} a^{(i)}(i=1 \sim 6)$ とすると， 1 次モードの応答を消去する ための初期条件式は以下の(11)式で表される。

$$
\psi_{1} a^{(1)} \dot{x}_{S}(0)+\psi_{1} a^{(4)} x_{S}(0)+\psi_{1} a^{(5)} x_{T 1}(0)+\psi_{1} a^{(6)} x_{T 2}(0)=0
$$

上式の左辺を実部と虚部の項に分けると, $\dot{x}_{S}(0), \mathrm{x}_{\mathrm{S}}(0), \mathrm{X}_{T 1}(0), \mathrm{X}_{\mathrm{T} 2}(0)$ がそれぞれ実数であることから，以下の二つの式が導かれる。

$\operatorname{Re}\left(\psi_{1} a^{(1)} \dot{x}_{S}(0)+\psi_{1} a^{(4)} x_{S}(0)+\psi_{1} a^{(5)} x_{T 1}(0)+\psi_{1} a^{(6)} x_{T 2}(0)\right)$

$=\operatorname{Re}\left(\psi_{1} \mathrm{a}^{(1)}\right) \dot{x}_{S}(0)+\operatorname{Re}\left(\psi_{1} a^{(4)}\right) x_{S}(0)+\operatorname{Re}\left(\psi_{1} a^{(5)}\right) x_{T 1}(0)+\operatorname{Re}\left(\psi_{1} a^{(6)}\right) x_{T 2}(0)=0$

$\operatorname{Im}\left(\psi_{1} a^{(1)} \dot{x}_{S}(0)+\psi_{1} a^{(4)} x_{S}(0)+\psi_{1} a^{(5)} x_{T 1}(0)+\psi_{1} a{ }^{(6)} x_{T 2}(0)\right)$

$=\operatorname{Im}\left(\psi_{1} a^{(1)}\right) \dot{x}_{S}(0)+\operatorname{Im}\left(\psi_{1} a^{(4)}\right) x_{S}(0)+\operatorname{Im}\left(\psi_{1} a^{(5)}\right) x_{T 1}(0)+\operatorname{Im}\left(\psi_{1} a^{(6)}\right) x_{T 2}(0)=0$

上式で未知変数が $\mathrm{X}_{\mathrm{T} 1}(0)$ と $\mathrm{X}_{\mathrm{T} 2}(0)$ の 2 個, 連立方程式の数が 2 個であ ることから, 解が一意に定まる。2 個の TMD の固有振動数が等しい 場合は, real $\left(\psi_{1} \mathrm{a}^{(5)}\right)=\operatorname{real}\left(\psi_{1} \mathrm{a}^{(6)}\right), \operatorname{imag}\left(\psi_{1} \mathrm{a}^{(5)}\right)=\operatorname{imag}\left(\psi_{1} \mathrm{a}^{(6)}\right)$ となり, 解が不定となる。以下の節では, 主振動系が初期変位または初期速度 のみを有する場合を例に取り，2 個の TMD の同調比の設定が主振動 系の応答と TMD 初期変位の大きさに与える影響を調べる。主振動系 の初期条件は $\mathrm{x}_{\mathrm{s}}(0)=0 \mathrm{~m}, \dot{x}_{\mathrm{s}}(0)=1 \mathrm{~m} / \mathrm{s}$ を基準とし, 5 章で述べる主振 動系の力学的全エネルギーの值が等しくなるように設定した。

\section{2 主振動系の初期条件が初期速度のみを有するとき}

2 個の TMD（TMD1,TMD2）の同調比を仮に(1) $\gamma_{1}=1.2, \gamma_{2}=0.8$ と (2) $\gamma_{1}=1.2, \gamma_{2}=1.1$ に設定した場合の二つのケースを比較する。

(1) $\gamma_{1}=1.2, \gamma_{2}=0.8$ のとき

3 個のモードの非減衰固有円振動数, 減衰固有振動数, モード減衰比 を以下に示す。

$$
\begin{aligned}
& \omega_{1}=9.917, \omega_{2}=7.988, \omega_{3}=12.12(\mathrm{rad} / \mathrm{s}) \\
& \omega_{1 \mathrm{D}}=9.912, \omega_{2 \mathrm{D}}=7.744, \omega_{3 \mathrm{D}}=11.74(\mathrm{rad} / \mathrm{s}) \\
& \xi_{1}=0.03221, \xi_{2}=0.2455, \xi_{3}=0.2478
\end{aligned}
$$

本モデルの1次モード減衰比は, 2次モードと3次モードの約 0.13 倍と非 常に小さい。2.3 節で述べた初期変位の付与により1次モードを消去 する条件は, 1次モードの応答が支配的となる通常のTMDでは不可能 な高い減衰を構造物に与え, 外力により生じる構造物の応答変位を小 さく, 且つ速やかに低減させることが可能となることが期待できる。 固有ベクトルのうちの変位ベクトルは以下のようになる。

$$
\begin{aligned}
& \boldsymbol{\Psi}_{1}=\left\{\begin{array}{c}
-0.01079 \mp 0.03016 \mathrm{i} \\
-0.05254 \mp 0.04821 \mathrm{i} \\
-0.04056 \pm 0.02709 \mathrm{i}
\end{array}\right\}, \boldsymbol{\psi}_{2}=\left\{\begin{array}{c}
-0.0006633 \mp 0.001150 \mathrm{i} \\
-0.0009218 \mp 0.002207 \mathrm{i} \\
-0.1052 \pm 0.003568 \mathrm{i}
\end{array}\right\}, \\
& \boldsymbol{\Psi}_{3}=\left\{\begin{array}{c}
-0.001329 \mp 0.001048 \mathrm{i} \\
0.02087 \pm 0.07924 \mathrm{i} \\
0.0006538 \pm 0.001327 \mathrm{i}
\end{array}\right\}
\end{aligned}
$$


(12)式と(13)式は，以下のようになる。

$$
\begin{aligned}
& -0.01079+0.002424 \mathrm{y}_{1}(0)-0.003755 \mathrm{y}_{2}(0)=0 \\
& -0.03016-0.006144 \mathrm{y}_{1}(0)-0.001802 \mathrm{y}_{2}(0)=0
\end{aligned}
$$

上式の TMD1 と TMD2 の初期変位 $\mathrm{y}_{1}(0)(\mathrm{m})$ と $\mathrm{y}_{2}(0)(\mathrm{m})$ の関係を Fig.4 に示す。黒丸で示した 2 本の直線の交点が 1 次モードの応答を 消去する TMD 初期変位 $\mathrm{y}_{1}(0)=-3.419 \mathrm{~m}, \mathrm{y}_{2}(0)=-5.081 \mathrm{~m}$ である。

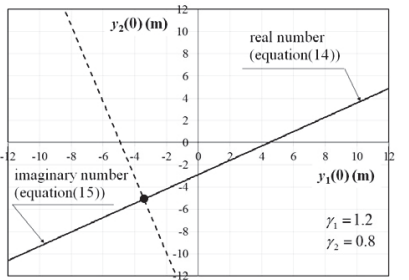

Fig. 4 Relationship between initial displacements of two TMDs

(2) $\gamma_{1}=1.2, \gamma_{2}=1.1$ のとき

$$
\begin{aligned}
& \omega_{1}=9.809, \omega_{2}=11.10, \omega_{3}=12.13 \\
& \omega_{1 \mathrm{D}}=9.804, \omega_{2 \mathrm{D}}=10.75, \omega_{3 \mathrm{D}}=11.75 \\
& \xi_{1}=0.03185, \xi_{2}=0.2465, \xi_{3}=0.2472
\end{aligned}
$$

変位ベクトルは以下のようになる。

$$
\begin{aligned}
& \boldsymbol{\psi}_{1}=\left\{\begin{array}{c}
-0.02207 \pm 0.03237 \mathrm{i} \\
-0.01174 \pm 0.08450 \mathrm{i} \\
0.009168 \pm 0.09558 \mathrm{i}
\end{array}\right\}, \boldsymbol{\psi}_{2}=\left\{\begin{array}{c}
0.001360 \pm 0.0001620 \mathrm{i} \\
0.009283 \pm 0.002700 \mathrm{i} \\
-0.04131 \mp 0.05521 \mathrm{i}
\end{array}\right\}, \\
& \boldsymbol{\psi}_{3}=\left\{\begin{array}{c}
-0.001465 \mp 0.001063 \mathrm{i} \\
0.02164 \pm 0.07779 \mathrm{i} \\
0.004982 \pm 0.007266 \mathrm{i}
\end{array}\right\}
\end{aligned}
$$

(12)式と(13)式は以下のようになる。

$$
\begin{aligned}
-0.02207-0.007673 \mathrm{y}_{1}(0)-0.007670 \mathrm{y}_{2}(0) & =0 \\
0.03237+0.001762 \mathrm{y}_{1(0)}+0.004100 \mathrm{y}_{2(0)} & =0
\end{aligned}
$$

上式の TMD1 と TMD2 の初期変位 $\mathrm{y}_{1}(0)(\mathrm{m})$ と $\mathrm{y}_{2}(0)(\mathrm{m})$ の関係を

Fig. 5 に示す。黒丸で示した 2 本の直線の交点が求める初期変位 $\mathrm{y}_{1}(0)=8.795 \mathrm{~m}, \mathrm{y}_{2}(0)=-11.68 \mathrm{~m}$ である。(1) $\gamma_{1}=1.2, \gamma_{2}=0.8$ と比較 寸ると, 実数值に関する直線と虚数值に関する直線の勾配が近くなり, 交点が原点から遠くなっている。

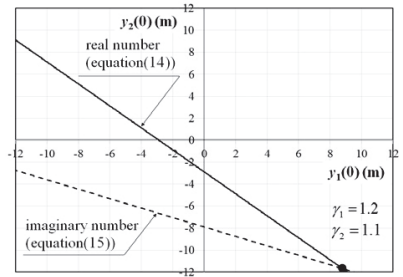

Fig. 5 Relationship between initial displacements of two TMDs

Fig.6 に既往の研究 6)で述べた質量比が $2 \%$ TMD が 1 個の場合に 1 次モードを消去する初期変位 $\mathrm{y}(0)=-2.127-0.1097 \mathrm{i}(\mathrm{m})$ の実数值の み与えた場合と, TMD が 2 個で(1) $\gamma_{1}=1.2, \gamma_{2}=0.8$ の場合, (2) $\gamma_{1}=1.2$, $\gamma_{2}=1.1$ の場合の自由振動応答曲線を比較する。TMD が 1 個の場合は 1 次モードの応答を完全に消去できないため, 5 秒以降も残留振動が 見られる。(1) $\gamma_{1}=1.2, \gamma_{2}=0.8$ の 2 個の TMD を用いる場合は, 同一質 量の 1 個の TMD を用いる場合よりも応答低減効果が大きい。一方, (2) $\gamma_{1}=1.2, \gamma_{2}=1.1$ の場合は応答が大きくなる。これは後述するように, 1 次モードを消去した残りの 2 次モードと 3 次モードの応答の振幅の 大きさが異なり，(2)の場合の方が大きいためである。

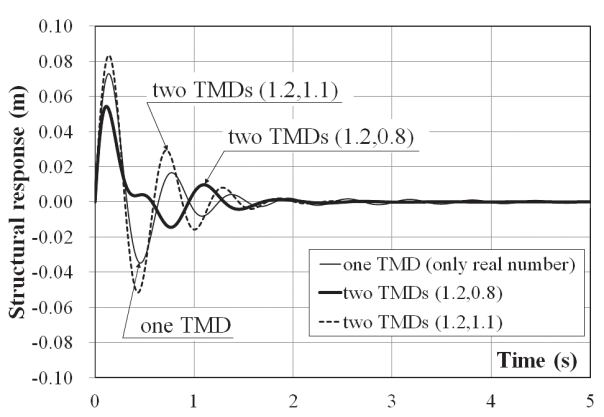

Fig. 6 Comparison of free vibration responses

制振効率をあらわす指標として，(18)式に示す主振動系の歪みエネ ルギーU $\mathrm{S}_{\mathrm{S}}$ と，(19)式に示す TMD に初期変位を付与することによる TMD の歪みエネルギーU 主振動系の振動応答時間 時間T は本論文では応答がほぼ収束する $2 \mathrm{~s}$ を用いた。

$$
\begin{aligned}
& U_{S}=\frac{1}{T} \int_{0}^{T} \frac{1}{2} K_{S} x_{S}(t)^{2} d t \\
& U_{T}=\frac{1}{2} K_{T 1} \mathrm{Y}_{1(0)}{ }^{2}+\frac{1}{2} K_{T 2} \mathrm{Y}_{2(0)}{ }^{2}
\end{aligned}
$$

Fig.7 と Fig.8 に 2 個の TMD の同調比と主振動系，TMD の歪み工 ネルギーのコンター図を示す。值が 0.027 または 50 を超える領域は 平面で切っている。両者のコンター曲面の形状は似ており, 主振動系 のエネルギーが小さい場合は TMD のエネルギーも小さい傾向が確認 できる。主振動系のエネルギーが最も小さくなるのは 2 個の TMD の 同調比が 1.20 と 0.73 のときであり, $0.01190 \mathrm{Nm}$ である。 2 個の TMD の同調比がともに 1 より小さいか 1 より大きい場合はエネルギーが非 常に大きくなる。なお TMD が 1 個のときの主振動系と TMD のエネ ルギーはそれぞれ $0.02741 \mathrm{Nm}, 4.344 \mathrm{Nm}$ である。

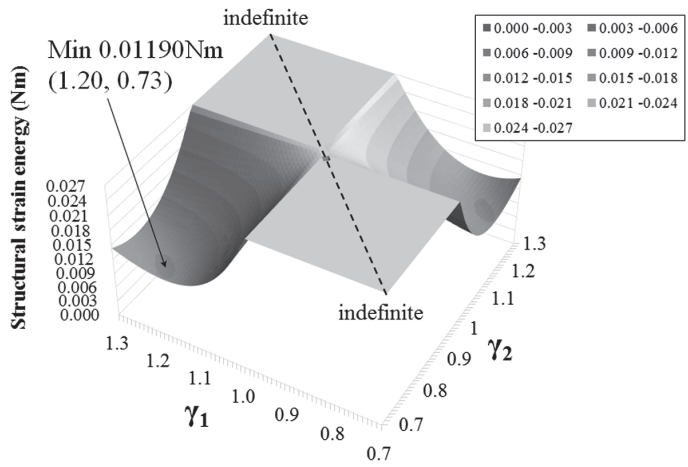

Fig. 7 Relationship between structural energy and tuning ratios

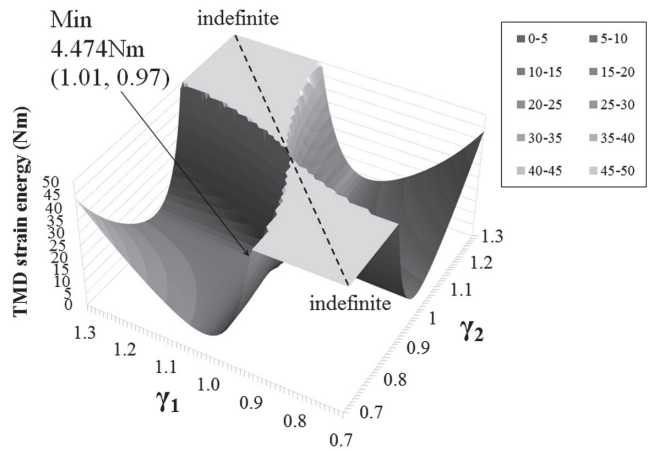

Fig. 8 Relationship between TMD energy and tuning ratios 


\section{3 主振動系の初期条件が初期変位のみを有するとき}

主振動系の初期条件が $\mathrm{x}_{\mathrm{s}}(0)=-0.1010 \mathrm{~m}, \dot{x}_{\mathrm{s}}(0)=0 \mathrm{~m} / \mathrm{s}$ のときの TMD の同調比と制振効果の関係を調べる。文献 6) で述べたように, この場合は 1 個の TMD では 1 次モードを消去できない。1 次モード の応答を消去する初期変位は (1) $\gamma_{1}=1.2, \gamma_{2}=0.8$ の場合が $\mathrm{x}_{\mathrm{T} 1}(0)=3.530 \mathrm{~m}, \quad \mathrm{x}_{\mathrm{T} 2}(0)=-5.839 \mathrm{~m}$, (2) $\gamma_{1}=1.2, \gamma_{2}=1.1$ の場合が $\mathrm{x}_{\mathrm{T} 1}(0)=16.93 \mathrm{~m}, \mathrm{x}_{\mathrm{T} 2}(0)=-12.70 \mathrm{~m}$ である。両者の自由振動応答曲線 を Fig.9 で比較する。前節で述べた初期速度のみを有する初期条件の 場合と同様に(1) $\gamma_{1}=1.2, \gamma_{2}=0.8$ の場合の方が制振効果が高い。

Fig.10 と Fig.11に 2 個の TMD の同調比と主振動系, TMD の歪み エネルギーのコンター図を示す。初期条件が初期速度のみを有する場 合とコンター形状は同様の傾向が見られるが, 主振動系のエネルギー は 2 個の TMD の同調比の間隔が大きくなるほど小さくなる。TMD のエネルギーは 2 個の TMD の同調比が 1.22 と 0.80 のときに最も小 さくなり，19.95Nm である。

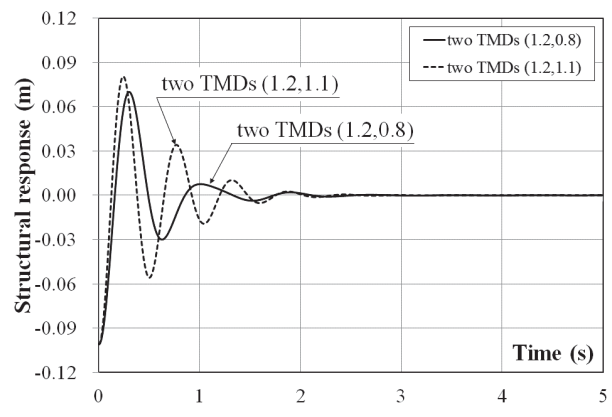

Fig. 9 Comparison of free vibration responses

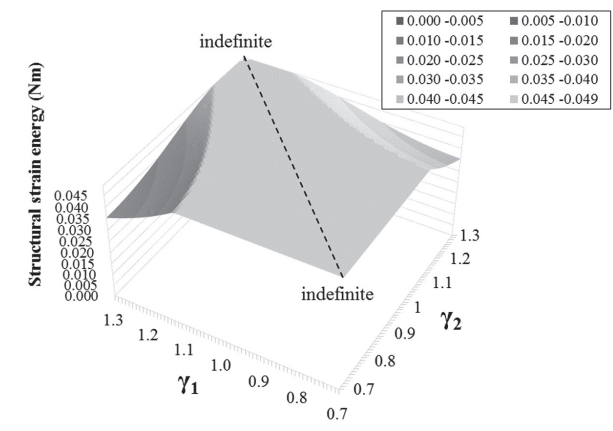

Fig. 10 Relationship between structural energy and tuning ratios

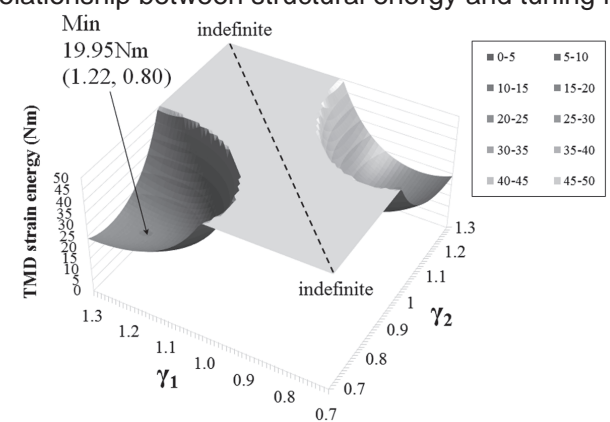

Fig. 11 Relationship between TMD energy and tuning ratios

\section{43 個の TMD を用いた場合}

主振動系の初期条件は前節と同じ $x_{\mathrm{s}}(0)=-0.1010 \mathrm{~m}, \dot{x}_{\mathrm{s}}(0)=0 \mathrm{~m} / \mathrm{s}$ と寸る。(11)式は以下のようになる。

$$
\psi_{1} a^{(5)} x_{S}(0)+\psi_{1} a^{(6)} x_{T 1}(0)+\psi_{1} a^{(7)} x_{T 2}(0)+\psi_{1} a^{(8)} x_{T 3}(0)=0
$$

TMD が 2 個のときと同様に，上式を実部の項と虚部の項に分けると 以下の二式が得られる。

$\operatorname{Re}\left(\psi_{1} a^{(5)} x_{S}(0)+\psi_{1} a^{(6)} x_{T 1}(0)+\psi_{1} a^{(7)} x_{T 2}(0)+\psi_{1} a^{(8)} x_{T 3}(0)\right)$

$=\operatorname{Re}\left(\psi_{1} \mathrm{a}^{(5)}\right) \mathrm{x}_{\mathrm{S}}(0)+\operatorname{Re}\left(\psi_{1} \mathrm{a}^{(6)}\right) \mathrm{x}_{\mathrm{T} 1}(0)+\operatorname{Re}\left(\psi_{1} \mathrm{a}^{(7)}\right) \mathrm{x}_{\mathrm{T} 2}(0)+\operatorname{Re}\left(\psi_{1} \mathrm{a}^{(8)}\right) \mathrm{x}_{\mathrm{T} 3}(0)=0$

$\operatorname{Im}\left(\psi_{1} a^{(5)} x_{S}(0)+\psi_{1} a^{(6)} x_{T 1}(0)+\psi_{1} a{ }^{(7)} x_{T 2}(0)+\psi_{1} a{ }^{(8)} x_{T 3}(0)\right)$

$=\operatorname{Im}\left(\psi_{1} a^{(5)}\right) x_{S}(0)+\operatorname{Im}\left(\psi_{1} a^{(6)}\right) x_{T 1}(0)+\operatorname{Im}\left(\psi_{1} a^{(7)}\right) x_{T 2}(0)+\operatorname{Im}\left(\psi_{1} a^{(8)}\right) x_{T 3}(0)=0$

上式を整理して，以下のように示す。

$$
\begin{aligned}
& A_{r} X_{T 1(0)}+B_{r} X_{T 2(0)}+C_{r} X_{T 3(0)}+D_{r}=0 \\
& A_{i} X_{T 1(0)}+B_{i} X_{T 2(0)}+C_{i} X_{T 3(0)}+D_{i}=0
\end{aligned}
$$

Fig.12 に示すように上式は TMD 初期変位 $\mathrm{x}_{\mathrm{T} 1}(0), \mathrm{x}_{\mathrm{T} 2}(0), \mathrm{x}_{\mathrm{T} 3}(0)$ で構 成される三次元空間に存在する平面を表す。二式を同時に満たす解は 2 つの平面の交線である。(23),(24)式より交線の式は以下のように求 められる。

$$
\begin{aligned}
& \frac{X_{T 1(0)}}{\left(B_{r} C_{i}-B_{i} C_{r}\right)}=\frac{X_{T 2(0)}+\left(D_{r} C_{i}-D_{i} C_{r}\right) /\left(B_{r} C_{i}-B_{i} C_{r}\right)}{-\left(A_{r} C_{i}-A_{i} C_{r}\right)} \\
& =\frac{X_{T 3(0)}+\left(D_{r} B_{i}-D_{i} B_{r}\right) /\left(C_{r} B_{i}-C_{i} B_{r}\right)}{\left(A_{r} B_{i}-A_{i} B_{r}\right)}
\end{aligned}
$$

同じ質量を有する 3 個の TMD の同調比が $\gamma_{1}=1.3, \gamma_{2}=1.1, \gamma_{3}=0.9$ の場合について検討する。TMD の減衰比と合計質量は TMD が 2 個 の場合と同じとする。交線の原点からの最短距離である垂線の足 （Fig.12の A 点）の座標は $\left(\mathrm{X}_{\mathrm{T} 1(0)}, \mathrm{X}_{\mathrm{T} 2(0)}, \mathrm{X}_{\mathrm{T}(0)}\right)=(5.708,2.222,-6.213)$ と なる。Fig.13 に垂線の足の TMD 初期変位を用いた場合 (Case A) と, 垂線の足以外の交線上の点 $\left(\mathrm{X}_{\mathrm{T} 1(0)}, \mathrm{X}_{\mathrm{T} 2(0)}, \mathrm{X}_{\mathrm{T} 3(0)}\right)=(0,8.123,-9.347)$ を用い た場合（Case B）の自由振動応答曲線を比較する。Case A の方が振 幅が小さく制振効果が高いことが確認できる。一方，Fig.9 で述べた TMD が 2 個で同調比が(1) $\gamma_{1}=1.2, \gamma_{2}=0.8$ の場合と比較すると制振効 果は同程度である。

以上より，複数個の TMD を用いたときの TMD 初期変位の大きさ と主振動系の応答の大きさには相関があり， 1 次モードを消去する TMD 初期変位が小さいほど主振動系の応答が小さい傾向があること が分かった。

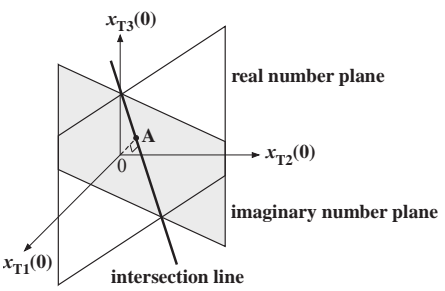

Fig. 12 Relationship between initial displacements of three TMDs

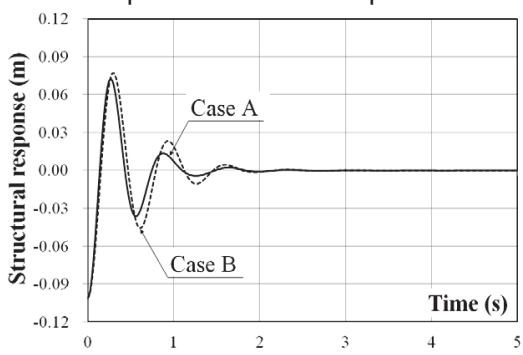

Fig. 13 Comparison of free vibration responses 


\section{4. 固有ベクトルを用いた考察}

前章で, TMD 同調比の設定と TMD 初期変位, 主振動系の応答の関 係を調べた。本章では TMD が 2 個の場合を例にとり, 主振動系／ TMD で構成される全体系の初期条件を固有モードベクトルに分解し, 複素平面上で固有ベクトルの和で表すことにより, 前章で述べた検討 結果について考察する。

\section{1 解の存在条件}

2 個の TMD を用い, 全体が 3 自由度系のモデルの固有ベクトルを $\boldsymbol{\kappa}_{1}, \boldsymbol{\kappa}_{2}, \boldsymbol{\kappa}_{3}$ とすると, 一般直交性より以下の $(26)$ 式が成り立つ。

$$
\kappa_{1} \mathbf{a} \kappa_{2}=0, \quad \kappa_{1} \mathbf{a} \kappa_{3}=0
$$

上式はベクトル $\boldsymbol{\kappa}_{1} \mathbf{a}$ が 2 次と 3 次の固有ベクトル $\boldsymbol{\kappa}_{2}$ と $\boldsymbol{\kappa}_{3}$ で形成され る平面に直交することを意味している。 3 次元空間における固有べク トルの関係のイメージ図を Fig.14に示す。

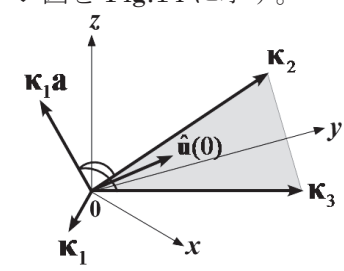

Fig. 14 Relationships between three eigenvectors

ベクトル $\kappa_{1} \mathrm{a}$ に直交する平面は一つしか存在しないため, 初期変位解 法条件式(7)式の初期条件べクトル $\hat{\mathbf{u}}(0)$ は, 2 次と 3 次の固有ベクト ルで形成される平面上に存在する。よって, 初期条件ベクトルは以下 のように 2 次と 3 次の固有ベクトルの線形和で表すことができる。

$$
\hat{\mathbf{u}}(0)=u \boldsymbol{\kappa}_{2}+v \boldsymbol{\kappa}_{3}
$$

上式が(7)式の初期変位解法条件式を満たすことは(26)式より明らか である。よって，(27)式を満足する実数の係数 U, $\mathrm{v}$ が存在するとき, 初期変位解法条件式を満たす解が存在することになる。なお, TMD の 個数が 3 個以上の場合は, 初期条件ベクトルは超平面上に存在する。

全体系の初期条件を, 主振動系の変位と速度がそれぞれ A, B , 2 個 の TMD (TMD1 と TMD2) の速度が 0 とする。一般粘性減衰系の固有 ベクトルは複素数であらわされるため, 複素平面上の実数值で解の存 在条件を表すと以下のようになる。

(1)主振動系の初期条件式

$$
\begin{aligned}
& \operatorname{Re}\left\{\mathrm{uS}_{\mathrm{D}}{ }^{2 \text { nd }}(\alpha)+\mathrm{vS}_{\mathrm{D}}{ }^{3 \mathrm{rd}}(\beta)\right\}=\mathrm{A} \\
& \operatorname{Re}\left\{\mathrm{uS_{V }}{ }^{2 \text { nd }}\left(\alpha+\theta_{V}{ }^{2 \text { nd }}\right)+\mathrm{vS}_{V}{ }^{3 r d}\left(\beta+\theta_{V}{ }^{3 r d}\right)\right\}=\mathrm{B}
\end{aligned}
$$

(2)TMD の初期条件式

$$
\begin{aligned}
& \operatorname{Re}\left\{u T 1_{v}{ }^{2 \text { nd }}\left(\alpha+\theta_{v}{ }^{2 n d}+\theta 1^{2 n d}\right)+v T 1_{v}{ }^{3 r d}\left(\beta+\theta_{v}{ }^{3 r d}+\theta 1^{3 r d}\right)\right\}=0 \\
& \operatorname{Re}\left\{\text { UT } 2_{v}{ }^{2 n d}\left(\alpha+\theta_{v}{ }^{2 n d}+\theta 2^{2 n d}\right)+v T 2_{v}{ }^{3 r d}\left(\beta+\theta_{v}{ }^{3 r d}+\theta 2^{3 r d}\right)\right\}=0
\end{aligned}
$$

上式で S , T1,T2 は, 主振動系, TMD1, TMD2 の固有ベクトルであ ることを示す。上付き記号はモード次数, 下付き記号 D, V は変位と 速度に関する物理量であることを示す。 $\alpha, \beta$ は複素平面での偏角に 係る変数であり, $\theta$ は全て固定值である。

(28)式と(29)式に示すように, TMD が 2 個の場合, 未知変数は固有 ベクトルの大きさに係る U, $\mathrm{v}$ と複素平面での偏角に係る $\alpha, \beta$ の 4 個 であり, 連立方程式の数と一致するため解は一意に定まる。一般に
$\mathrm{TMD}$ の個数が $\mathrm{N}$ 個のとき, 未知量の数は N 個のモードの固有ベクト ルに係る大きさと偏角の $2 \mathrm{~N}$ 個であり, 初期条件の連立方程式の数は 主振動系の初期条件 2 個と TMD の初期条件 N 個の和 N + 2 個となる。 よって, 未知量と連立方程式の数の差は, N - 2 個である。

以上より, TMDの個数と解の関係は以下のようになる。

(1)TMD が 1 個のときには，解は存在しない。

(2)TMD が 2 個のときには，解は一意に定まる。

(3)TMD が 3 個以上のときには, 解が不定となり, 無数に存在する。

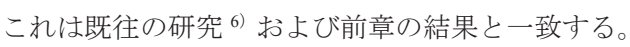

\section{2 初期条件の固有モード分解}

本節では，前章で述べた 2 個の TMD の同調比の設定と主振動系の 応答, TMD 初期変位の関係について, 初期条件式(28)式と(29)式を用 いて考察する。主振動系の初期条件は，3.3節と同じ $x_{s}(0)=-0.1010$ $\mathrm{m}, \dot{\mathrm{x}}_{\mathrm{s}}(0)=0 \mathrm{~m} / \mathrm{s}$ とする。

(1) $\gamma_{1}=1.2, \gamma_{2}=0.8$ の場合

主振動系の自由振動応答変位は以下の $(30)$ 式で表される。非減衰固有 円振動数 $\omega_{2 D}, \omega_{3 D}$ については，3．2節(1)に示した。

$\mathrm{x}_{\mathrm{S}}(\mathrm{t})=\mathrm{e}^{-0.2455 \omega_{2} \mathrm{t}} \times 0.07682 \sin \left(\omega_{2 D} \mathrm{t}+\theta_{2}\right)+\mathrm{e}^{-0.2478 \omega_{3} \mathrm{t}} \times 0.07653 \sin \left(\omega_{3 \mathrm{D}} \mathrm{t}+\theta_{3}\right)$

ここで, $\theta_{2}=-42.42$ (deg.), $\theta_{3}=-140.0$ (deg.)

TMD1 の自由振動応答変位は以下の式で表される。

$\mathrm{x}_{\mathrm{T} 1}(\mathrm{t})=\mathrm{e}^{-0.245 \omega_{2} \mathrm{t}} \times 0.1385 \sin \left(\omega_{2 \mathrm{D}} \mathrm{t}+\theta_{2}\right)+\mathrm{e}^{-0.2478 \omega_{3} \mathrm{t}} \times 3.705 \sin \left(\omega_{30} \mathrm{t}+\theta_{3}\right)$

ここで, $\theta_{2}=-35.10$ (deg.), $\theta_{3}=76.97$ (deg.)

TMD2 の自由振動応答変位は以下の式で表される。

$\mathrm{X}_{\mathrm{T} 2}(\mathrm{t})=\mathrm{e}^{-0.2455 \omega_{2} \mathrm{t}} \times 6.090 \sin \left(\omega_{2 D} \mathrm{t}+\theta_{2}\right)+\mathrm{e}^{-0.2478 \omega_{3} \mathrm{t}} \times 0.06687 \sin \left(\omega_{3 \mathrm{D}} \mathrm{t}+\theta_{3}\right)$

ここで, $\theta_{2}=-104.4$ (deg.), $\theta_{3}=65.49$ (deg.)

(30)式 (32)式を $\sin \theta=\cos (\pi / 2-\theta)$ の関係を用いて, $\mathrm{t}=0$ のときの初 期変位条件を複素平面上で 2 次モードと 3 次モードの変位ベクトルの 和で表すと Fig.15 のようになる。実軸の值が実際の変位に対応する。 (28)式と(29)式における $\alpha, \beta$ は 132.4,230.0(deg.)であり, $\theta 1^{2 \text { nd }}, \theta 1^{3 \text { rd }}$ は $-7.3,143.0$ (deg.) $, \theta 2^{2 \text { nd }}, \theta 2^{3 \text { rd }}$ は 62.0, 154.5(deg.)である。 2 次モー ドと 3 次モードの主振動系の変位ベクトルの和の実軸への投影長さは, 主振動系の初期条件 $\mathrm{x}_{\mathrm{s}}(0)=-0.1010 \mathrm{~m}$ である。TMD1 と TMD2 におけ る 2 個のモードの実軸への投影長さの和は，3．３節で述べた TMD 初期変位 $\mathrm{x}_{\mathrm{T}_{1}}(0)=3.530 \mathrm{~m}, \quad \mathrm{x}_{\mathrm{T} 2}(0)=-5.839 \mathrm{~m}$ である。

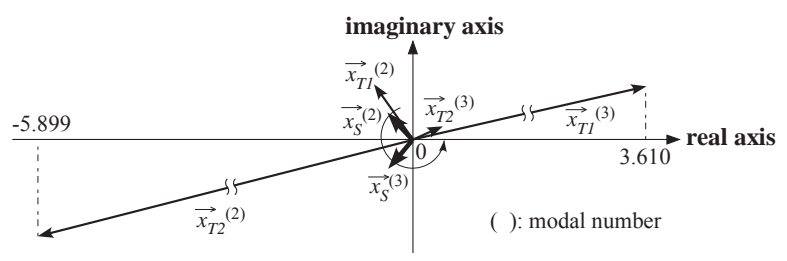

Fig. 15 Initial displacement condition on the complex plane

(2) $\gamma_{1}=1.2, \gamma_{2}=1.1$ の場合

主振動系の自由振動応答変位は以下の $(33)$ 式のように表される。非減 衰固有円振動数 $\omega_{2 \mathrm{D}}, \omega_{3 \mathrm{D}}$ については，3．2 節(2)に示した。

$\mathrm{x}_{\mathrm{S}}(\mathrm{t})=\mathrm{e}^{-0.2465 \omega_{2} \mathrm{t}} \times 0.2939 \sin \left(\omega_{2 D} \mathrm{t}+\theta_{2}\right)+\mathrm{e}^{-0.2472 \omega_{3} \mathrm{t}} \times 0.3571 \sin \left(\omega_{3 \mathrm{D}} \mathrm{t}+\theta_{3}\right)$ 
TMD1 の自由振動応答変位は以下のように表される。 $\mathrm{X}_{\mathrm{T} 1}(\mathrm{t})=\mathrm{e}^{-0.2465 \omega_{2} \mathrm{t}} \times 2.075 \sin \left(\omega_{2 \mathrm{D}} \mathrm{t}+\theta_{2}\right)+\mathrm{e}^{-0.2472 \omega_{3} \mathrm{t}} \times 15.93 \sin \left(\omega_{3 \mathrm{D}} \mathrm{t}+\theta_{3}\right)$

$$
\text { ここで, } \theta_{2}=36.90 \text { (deg.), } \theta_{3}=79.97 \text { (deg.) }
$$

TMD2 の自由振動応答変位は以下のように表される。

$\mathrm{X}_{\mathrm{T} 2}(\mathrm{t})=\mathrm{e}^{-0.2465 \omega_{2} \mathrm{t}} \times 14.80 \sin \left(\omega_{2 \mathrm{D}} \mathrm{t}+\theta_{2}\right)+\mathrm{e}^{-0.2472 \omega_{3} \mathrm{t}} \times 1.738 \sin \left(\omega_{3 \mathrm{D}} \mathrm{t}+\theta_{3}\right)$

ここで, $\theta_{2}=-106.1$ (deg.), $\theta_{3}=61.08$ (deg.)

$\mathrm{t}=0$ のときの初期変位条件を複素平面上で 2 次モードと 3 次モード のベクトルの和で表すと Fig.16のようになる。(28)式と(29)式におけ る $\alpha, \beta$ は 62.5, 228.5(deg.)であり， $\theta 1^{2 \text { nd }}, \theta 1^{3 \text { rd }}$ は-9.4, 141.5(deg.), $\theta 2^{2 \text { nd }}, \theta 2^{3 \text { rd }}$ は $133.6,160.4(\mathrm{deg}$.$) である。$

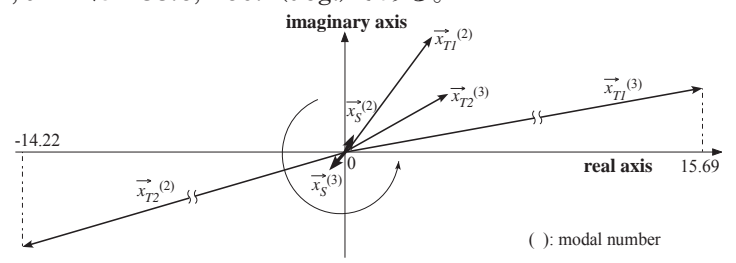

Fig. 16 Initial displacement condition on the complex plane

以上のように, (2) $\gamma_{1}=1.2, \gamma_{2}=1.1$ の場合は(1) $\gamma_{1}=1.2, \gamma_{2}=0.8$ の場 合と比較して, 主振動系に対する 2 次モードの TMD2 の位相差が 62.0(deg.)から 133.6(deg.) 一大きく変化している。また, Fig.15と Fig.16 に示すように, 2 次モードと 3 次モードの主振動系のベクトル が存在する象限が，(1) $\gamma_{1}=1.2, \gamma_{2}=0.8$ の場合は第 2 象限と第 3 象限 で実軸に関して隣り合っていたのに対して, (2) $\gamma_{1}=1.2, \gamma_{2}=1.1$ の場合 は第 1 象限と第 3 象限と原点に関して対称の位置に存在する。

参考のために, 初期速度の条件に関して, (1) $\gamma_{1}=1.2, \gamma_{2}=0.8$ の場合 を複素平面上で Fig.17 に示す。主振動系と TMD の初期速度が 0 とな る条件を満たしていることが確認できる。なお, 速度べクトルと変位 ベクトルの位相差 $\theta_{v}{ }^{2 \text { nd }}, \theta_{v}^{3 \text { rd }}$ は各モードで共通であり, (1) $\gamma_{1}=1.2$, $\gamma_{2}=0.8$ の場合は 2 次と 3 次でそれぞれ 104.2, 104.4(deg.), (2) $\gamma_{1}=1.2$, $\gamma_{2}=1.1$ の場合は 104.3, 104.3(deg.) とほぼ同じである。これは 2 次モ ードと 3 次モードの減衰比の值が非常に近いためである。

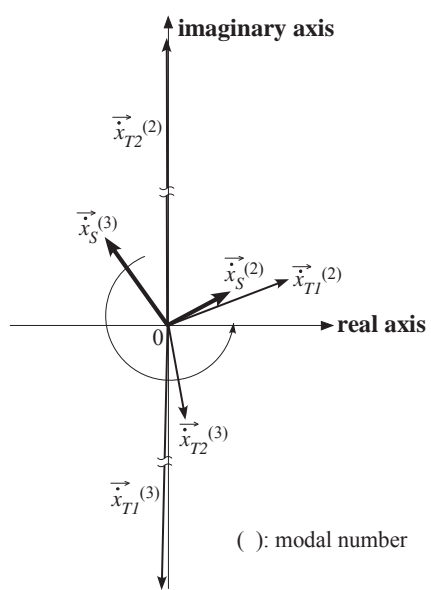

Fig. 17 Initial velocity condition on the complex plane

初期変位条件に関する考察結果に基づき, 主振動系の初期変位べク トルが複素平面上に存在する象限を Fig.18 に示す。 2 個の TMD の同 調比 $\gamma_{1}, \gamma_{2}$ がともに 1 より小さいか 1 より大きい場合は原点に対して
対称の位置にある象限に存在し，それ以外の場合は実軸に対して隣り 合う象限に存在する。これは Fig.10，Fig.11のエネルギーのコンター 図において, TMD の同調比がともに 1 より小さいか 1 より大きい場 合はエネルギーが非常に大きくなる性状と対応する。主振動系の初期 条件が $\mathrm{x}_{\mathrm{S}}(0)=0 \mathrm{~m}, \dot{\mathrm{x}}_{\mathrm{s}}(0)=1 \mathrm{~m} / \mathrm{s}$ のときに主振動系の初期速度ベクト ルが存在する象限を Fig.19に示す。Fig.18の場合と同様に，TMDの 同調比がともに 1 より小さいか 1 より大きい場合は原点または虚軸に 対して対称の位置にある象限に存在し，それ以外の場合は実軸に関し て隣り合う象限または同じ象限に位置し，Fig.7，Fig.8のエネルギー 曲面の性状と対応している。

\begin{tabular}{|c|c|c|c|c|c|c|c|c|c|c|c|c|c|c|}
\hline & $\gamma_{2}$ & 0.70 & 0.75 & 0.80 & 0.85 & 0.90 & 0.95 & 1.00 & 1.05 & 1.10 & 1.15 & 1.20 & 1.25 & 1.30 \\
\hline$\gamma_{1}$ & & & & & & & & & & & & & & \\
\hline 0.70 & & & 4,2 & 4,2 & 4,2 & 4,2 & 4,2 & 3,2 & 3,2 & 3,2 & 3,2 & 3,2 & 2,3 & 2,3 \\
\hline 0.75 & & 4,2 & & 4,2 & 4,2 & 4,2 & 4,2 & 3,2 & 3,2 & 3,2 & 3,2 & 2,3 & 2,3 & 2,3 \\
\hline 0.80 & & 4,2 & 4,2 & & 4,2 & 4,2 & 4,2 & 3,2 & 3,2 & 3,2 & 2,3 & 2,3 & 2,3 & 2,3 \\
\hline 0.85 & & 4,2 & 4,2 & 4,2 & & 4,2 & 4,2 & 3,2 & 3,2 & 2,3 & 2,3 & 2,3 & 2,3 & 2,3 \\
\hline 0.90 & & 4,2 & 4,2 & 4,2 & 4,2 & & 4,2 & 3,2 & 3,2 & 2,3 & 2,3 & 2,3 & 2,3 & 2,3 \\
\hline 0.95 & & 4,2 & 4,2 & 4,2 & 4,2 & 4,2 & & 3,2 & 3,2 & 2,3 & 2,3 & 2,3 & 2,3 & 2,3 \\
\hline 1.00 & & 3,2 & 3,2 & 3,2 & 3,2 & 3,2 & 3,2 & & 3,1 & 1,3 & 1,3 & 1,3 & 1,3 & 1,3 \\
\hline 1.05 & & 3,2 & 3,2 & 3,2 & 3,2 & 3,2 & 3,2 & 3,1 & & 3,1 & 1,3 & 1,3 & 1,3 & 1,3 \\
\hline 1.10 & & 3,2 & 3,2 & 3,2 & 2,3 & 2,3 & 2,3 & 1,3 & 3,1 & & 3,1 & 1,3 & 1,3 & 1,3 \\
\hline 1.15 & & 3,2 & 3,2 & 2,3 & 2,3 & 2,3 & 2,3 & 1,3 & 1,3 & 3,1 & & 3,1 & 1,3 & 1,3 \\
\hline 1.20 & & 3,2 & 2,3 & 2,3 & 2,3 & 2,3 & 2,3 & 1,3 & 1,3 & 1,3 & 3,1 & & 3,1 & 1,3 \\
\hline 1.25 & & 2,3 & 2,3 & 2,3 & 2,3 & 2,3 & 2,3 & 1,3 & 1,3 & 1,3 & 1,3 & 3,1 & & 3,1 \\
\hline 1.30 & & 2,3 & 2,3 & 2,3 & 2,3 & 2,3 & 2,3 & 1,3 & 1,3 & 1,3 & 1,3 & 1,3 & 3,1 & \\
\hline
\end{tabular}

Fig. 18 Quadrants of initial structural vectors (displacement condition)

\begin{tabular}{|c|c|c|c|c|c|c|c|c|c|c|c|c|c|c|}
\hline & $\gamma_{2}$ & 0.70 & 0.75 & 0.80 & 0.85 & 0.90 & 0.95 & 1.00 & 1.05 & 1.10 & 1.15 & 1.20 & 1.25 & 1.30 \\
\hline$\gamma_{1}$ & & & & & & & & & & & & & & \\
\hline 0.70 & & & 1,3 & 1,3 & 1,3 & 1,3 & 4,3 & 4,1 & 4,1 & 4,1 & 4,1 & 4,1 & 1,4 & 1,4 \\
\hline 0.75 & & 1,3 & & 1,3 & 1,3 & 1,3 & 4,3 & 4,4 & 4,1 & 4,1 & 4,1 & 1,4 & 1,4 & 1,4 \\
\hline 0.80 & & 1,3 & 1,3 & & 1,3 & 1,3 & 4,3 & 4,4 & 4,1 & 4,1 & 1,4 & 1,4 & 1,4 & 1,4 \\
\hline 0.85 & & 1,3 & 1,3 & 1,3 & & 1,3 & 1,3 & 4,4 & 4,1 & 1,4 & 1,4 & 1,4 & 1,4 & 1,4 \\
\hline 0.90 & & 1,3 & 1,3 & 1,3 & 1,3 & & 1,3 & 4,4 & 4,1 & 1,4 & 1,4 & 1,4 & 1,4 & 1,4 \\
\hline 0.95 & & 4,3 & 4,3 & 4,3 & 1,3 & 1,3 & & 4,4 & 4,4 & 4,4 & 4,4 & 4,4 & 4,4 & 4,4 \\
\hline 1.00 & & 4,1 & 4,4 & 4,4 & 4,4 & 4,4 & 4,4 & & 2,4 & 4,2 & 4,2 & 4,2 & 4,2 & 4,2 \\
\hline 1.05 & & 4,1 & 4,1 & 4,1 & 4,1 & 4,1 & 4,4 & 2,4 & & 2,4 & 4,2 & 4,2 & 4,2 & 4,2 \\
\hline 1.10 & & 4,1 & 4,1 & 4,1 & 1,4 & 1,4 & 4,4 & 4,2 & 2,4 & & 2,4 & 4,2 & 4,2 & 4,2 \\
\hline 1.15 & & 4,1 & 4,1 & 1,4 & 1,4 & 1,4 & 4,4 & 4,2 & 4,2 & 2,4 & & 2,4 & 4,2 & 4,2 \\
\hline 1.20 & & 4,1 & 1,4 & 1,4 & 1,4 & 1,4 & 4,4 & 4,2 & 4,2 & 4,2 & 2,4 & & 2,4 & 4,2 \\
\hline 1.25 & & 1,4 & 1,4 & 1,4 & 1,4 & 1,4 & 4,4 & 4,2 & 4,2 & 4,2 & 4,2 & 2,4 & & 2,4 \\
\hline 1.30 & & 1,4 & 1,4 & 1,4 & 1,4 & 1,4 & 4,4 & 4,2 & 4,2 & 4,2 & 4,2 & 4,2 & 2,4 & \\
\hline
\end{tabular}

Fig. 19 Quadrants of initial structural vectors (velocity condition)

Fig.20 は同じ主振動系の初期変位条件 $\mathrm{x}_{\mathrm{S}}(0)$ を有するときに, 2 次 モードと 3 次モードの主振動系の初期変位ベクトル $\vec{x}_{5}{ }^{(2)}, \vec{x}_{5}{ }^{(3)}$ が存在 する象限の違いが 2 個のモードの変位ベクトルの大きさに与える影響 を説明した図である。(a)の実軸に対して隣り合う象限に存在する場合 は，初期条件が各モードの実軸への投影長さの和となる。一方，(b)の 原点に対して対称の象限に存在する場合は, 初期条件が各モードの実 軸への投影長さの差となるため，2 個のモードの実軸への投影長さの 和は初期条件 $\mathrm{x}_{\mathrm{S}}(0)$ よりも大きくなる。前述の(2) $\gamma_{1}=1.2, \gamma_{2}=1.1$ は Fig.20(b)の場合に相当し, (a)の(1) $\gamma_{1}=1.2, \gamma_{2}=0.8$ の場合と比較して, 初期変位ベクトルの大きさは 2 次モードで 3.83 倍, 3 次モードで 4.67 倍に大きくなる。

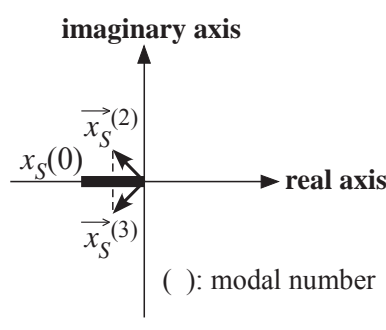

(a) Adjacent quadrant

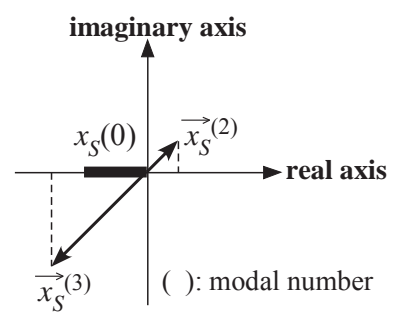

(b) Symmetrical quadrant
Fig. 20 Comparison of arrangement of initial structural vectors 
以下では, 主振動系の初期条件について, 複素平面上で 2 次モード と 3 次モードの存在する象限が異なる要因を調べる。ここでは, 2 次 と 3 次の固有ベクトルに関して, 2 個の TMDの同調比が変化した場 合における主振動系を基準とした TMD 固有ベクトルの大きさと位相 差の変化に着目する。Fig.15 と Fig.16の結果に基づいて, 2 次モード と 3 次モードの TMD1 固有ベクトルのうちの大きい方のモードを選 択し, 主振動系の固有ベクトルの大きさで基準化した TMD1 固有ベク トルの絶対值を Fig.21 に, TMD1 固有ベクトルの主振動系に対する 位相差を Fig. 22 に示す。両図とも TMD1 と TMD2 の同調比が等しく なる近傍では值の変化が大きくなる。

Fig.21 に示す TMD1 固有ベクトルの大きさに関して, TMD2 の同 調比 $\gamma_{2}$ の変動に対してはあまり敏感でない。一方, TMD1 の同調比 $\gamma_{1}$ の変動に対し， $\gamma_{1}$ が 0.8 よりも大きい場合は值の変化が小さいが, 0.7 に近づくと急激に大きくなる。Fig. 22 に示す TMD1 固有ベクトルの 主振動系に対する位相差に関して, TMD2 の同調比 $\gamma_{2}$ の変動に対して はあまり敏感ではないが, TMD1 の同調比 $\gamma_{1}$ の変動に対しては変化が 大きい。これは Fig.16 で説明した(1) $\gamma_{1}=1.2, \gamma_{2}=0.8$ のときはTMD2 の位相差が 62.0(deg.) であるが, (2) $\gamma_{1}=1.2, \gamma_{2}=1.1$ のときは 133.6(deg.) と TMD2 の位相差が大きく変化することに対応する。 $\gamma_{1}=1.0$ のときの位相差は約 100 110(deg.)である。以上のことから， 2 個の TMD の同調比の設定の違いが主振動系の初期条件の存在象限 に与える影響は，位相差の変化によるものが大きいと考えられる。

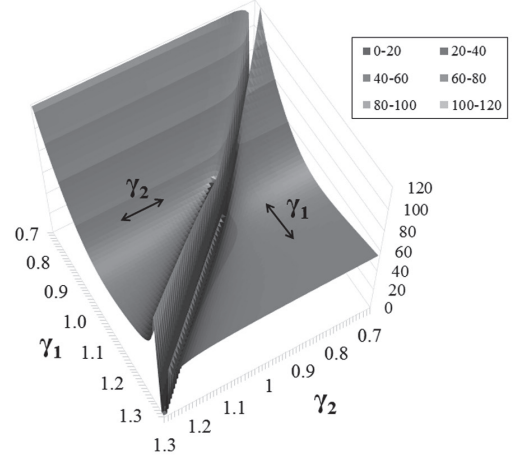

Fig. 21 Absolute value of TMD1 eigenvector

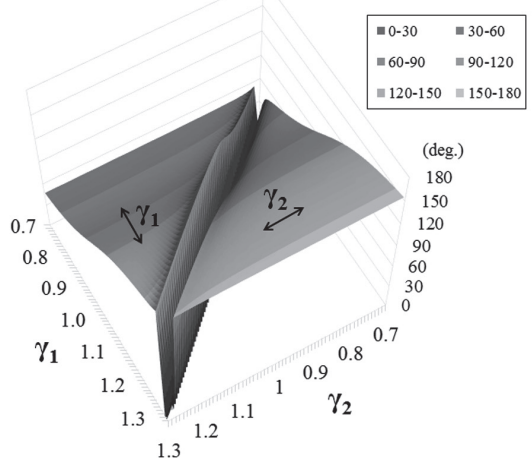

Fig. 22 Phase difference of TMD1 eigenvector

\section{TMD power flow を用いた考察}

本章では，初期変位付与型 TMD の制振効果および 2 個の TMD の 同調比の設定が制振効果に与える影響について, Soong, T.T. と Dargush, G.F.により提案されたエネルギー指標である TMD power flow ${ }^{14)}$ を用いて考察する。

\section{1 定式化と初期変位付与型 TMD における power flow}

最初に, TMD が 1 個の場合の初期変位付与型 TMD の制振効果を TMD power flow を用いて確認する。Fig.1 に示す主振動系と 1 個の $\mathrm{TMD}$ からなる 2 自由度系の自由振動運動方程式は以下の式で表すこ とができる。

$\left[\begin{array}{cc}M_{S} & 0 \\ 0 & m_{T}\end{array}\right]\left\{\begin{array}{l}\dot{x}_{S} \\ \dot{x}_{T}\end{array}\right\}+\left[\begin{array}{cc}c_{S}+c_{T} & -c_{T} \\ -c_{T} & c_{T}\end{array}\right]\left\{\begin{array}{l}\dot{x}_{S} \\ \dot{x}_{T}\end{array}\right\}+\left[\begin{array}{cc}K_{S}+k_{T} & -k_{T} \\ -k_{T} & k_{T}\end{array}\right]\left\{\begin{array}{l}x_{S} \\ x_{T}\end{array}\right\}=\left\{\begin{array}{l}0 \\ 0\end{array}\right\} \quad(36)$ TMD の主振動系に対する相対変位をyとすると，上式は以下のよう に表すことができる。

$$
\begin{aligned}
& M_{S} \ddot{x}_{S}+c_{S} \dot{x}_{S}+K_{S} x_{S}=c_{T} \dot{y}+k_{T} y \\
& m_{T} \ddot{y}+c_{T} \dot{y}+k_{T} y=-m_{T} \ddot{x}_{S}
\end{aligned}
$$

(38)式を(37)式に代入すると，以下の式が得られる。

$$
\left(M_{S}+m_{T}\right) \ddot{x}_{S}+C_{S} \dot{x}_{S}+K_{S} x_{S}+m_{T} \ddot{y}=0
$$

Soong, T.T.らは(39)式に $\dot{x}_{S}$ を乗じ, 調和外力が作用した場合の第 4 項 の 1 サイクルの時間平均 $m_{\mathrm{T}}\left\langle\ddot{y}_{\mathrm{S}}\right\rangle$ を主振動系から TMD へ power flow と定義し，定常調和応答の場合における TMD の制振効果を表す 指標として用いた ${ }^{14)}$ 。

(39)式を主振動系の変位で積分すると，以下のようになる。

$$
\int\left(M_{S}+m_{T}\right) \dot{x}_{S} d x_{S}+\int C_{S} \dot{x}_{S} d x_{S}+\int K_{S} x_{S} d x_{S}+\int m_{T} \ddot{y} d x_{S}=E_{S}
$$

上式で $\mathrm{E}_{\mathrm{S}}$ は定数であり，自由振動の場合は外部からエネルギーが入 力されずエネルギ一保存則が成立するため，主振動系の初期条件によ り付与された一定の值となる。(40)式に $\mathrm{dx}_{\mathrm{s}}=\left(\mathrm{dx}_{\mathrm{s}} / \mathrm{dt}\right) \mathrm{dt}=\dot{\mathrm{x}}_{\mathrm{s}} \mathrm{dt}$ を代入 すると以下のようになる。

$$
\left(M_{S}+m_{T}\right) \int \dot{x}_{S} \dot{x}_{S} d t+C_{S} \int \dot{x}_{S}^{2} d t+K_{S} \int x_{S} \dot{x}_{S} d t+m_{T} \int \ddot{y}_{1} \dot{x}_{S} d t=E_{S}
$$

以下の(42)式の関係を用いると,(41)式は(43)式のように書き表すこと ができる。

$$
\begin{gathered}
\frac{d\left(x_{S}{ }^{2}\right)}{d t}=\frac{d\left(x_{S}^{2}\right)}{d x_{S}} \frac{d x_{S}}{d t}=2 x_{S} \dot{x}_{S}, \frac{d\left(\dot{x}_{S}^{2}\right)}{d t}=\frac{d\left(\dot{x}_{S}^{2}\right)}{d \dot{x}_{S}} \frac{d \dot{x}_{S}}{d t}=2 \dot{x}_{S} \dot{x}_{S} \\
\frac{1}{2}\left(M_{S}+m_{T}\right) \dot{x}_{S}{ }^{2}+\frac{1}{2} K_{S} x_{S}{ }^{2}+C_{S} \int \dot{x}_{S}{ }^{2} d t+m_{T} \int \ddot{y} \dot{x}_{S} d t=E_{S}
\end{gathered}
$$

上式で主振動系のエネルギーを消費する減衰効果は, 主振動系の減衰 による項 $C_{S} \int \dot{x}_{S}{ }^{2} \mathrm{dt}$ と TMD による付加減衰を表す TMD power flow の 項 $m_{T} \int \ddot{y} \dot{x}_{S} d t$ の和となる。 $m_{T} \int \ddot{y} \dot{x}_{S} d t$ の項中の $\ddot{y} \dot{x}_{S}$ で分かるように TMD の制振効果を評価するためには，主振動系と TMD の応答の相 対的な関係に着目する必要がある。また，初期変位付与型 TMD にお ける初期変位の付与効果は $\mathrm{m}_{\mathrm{T}} \int \ddot{y}_{\mathrm{x}} \mathrm{dt}$ の項における $\mathrm{y}$ ，すなわち TMD の主振動系に対する相対加速度の大きさの増加と考えられる。

既往の研究 6) より，TMD が 1 個の場合，主振動系の初期条件が $\mathrm{X}_{\mathrm{S}}(0)=0, \dot{\mathrm{x}}_{\mathrm{S}}(0) \neq 0$ のときは 1 次モードの応答をほぼ消去可能なこと が分かっている。そこで, 主振動系の初期条件を $\mathrm{x}_{\mathrm{s}}(0)=0 \mathrm{~m}, \dot{\mathrm{x}}_{\mathrm{s}}(0)=1$ $\mathrm{m} / \mathrm{s}$ に設定して検討する。TMD の質量比は $2 \%$ とし，同調比は(5)式を 用いて 0.9787 , 減衰比は TMD が 2 個の場合と同じ 0.2517 に設定す る。なお，主振動系の初期条件が $\mathrm{x}_{\mathrm{s}}(0) \neq 0, \dot{\mathrm{x}}_{\mathrm{s}}(0)=0$ のときに 1 次モ 一ドの応答をほぼ消去可能な解，すなわち初期変位付与型 TMD とし て有意な解が存在しないのは，2 次モードの TMD と主振動系の固有 ベクトルの位相差が-100.5 (deg.)であるため, 主振動系と TMD の速 度がともに 0 となる条件 $\dot{\mathrm{X}}_{\mathrm{S}}(0)=\dot{\mathrm{X}}_{\mathrm{T}}(0)=0$ を満足する解が存在しない ためである。 
Fig.23(a)に初期変位が無い場合における(43)式の各項，すなわち主 振動系の運動エネルギー, 歪みエネルギー, 減衰エネルギー, TMD power flow の時刻歴の推移を示す。主振動系の減衰エネルギー, TMD power flow の増加に伴い, 運動エネルギーと歪みエネルギーが時間の 経過とともに減少していることが分かる。3．２節で述べた TMD 初 期変位 $\mathrm{y}(0)=-2.127-0.1097 \mathrm{i}(\mathrm{m})$ のうち, 実数值 $-2.127 \mathrm{~m}$ のみを用い た場合における TMD power flow の時刻歴の推移を Fig.23(b)に示す。 振動開始直後から TMD power flow が急激に増加し, 運動エネルギー と歪みエネルギーが大きく減少しており, 初期変位付与型 TMD によ る大きな付加減衰効果が確認できる。

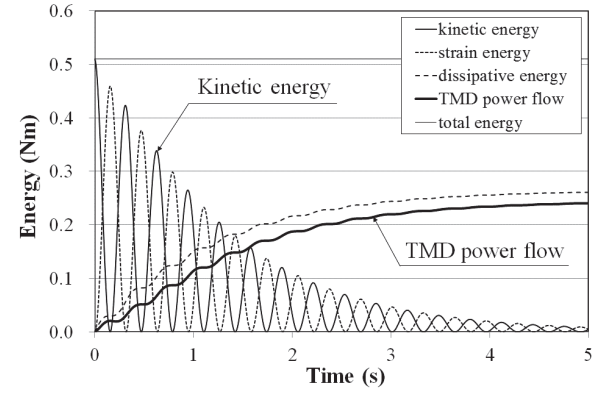

(a) Without initial displacement

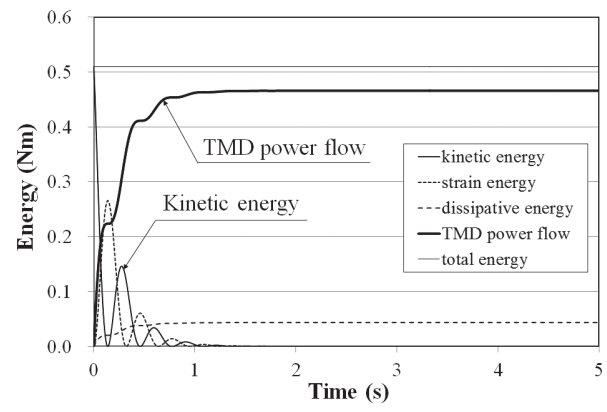

(b) With initial displacement

Fig. 23 Time histories of one TMD power flow

\section{22 個の TMD の同調比の設定による power flow の比較}

本節では, 2 個の TMD の同調比の設定が異なるときの TMD power flow の時刻歴の推移を比較する。主振動系の初期条件は $\mathrm{x}_{\mathrm{s}}(0)=-0.1010 \mathrm{~m}, \dot{x}_{\mathrm{s}}(0)=0 \mathrm{~m} / \mathrm{s}$ とする。

3. 3 節で述べた 1 次モードを消去する TMD 初期変位を与え, 2 個の TMD の同調比が(1) $\gamma_{1}=1.2, \gamma_{2}=0.8$ の場合を Fig.24(a)に, (2) $\gamma_{1}=1.2, \gamma_{2}=1.1$ の場合を Fig.24(b)に示す。TMD1の power flow につ いて, (1)の場合は応答初期の $0.20 \mathrm{~s}$ までは負の值であるが，その後は 正の值となる。(2)の場合は時刻歴全体で負の值である。TMD2 の power flow 值は(2)の場合の方が大きい。最終的な TMD1 と TMD2 の 合計の power flow 值は, (1)の場合が 0.4439 , (2)の場合が 0.3848 であ り, (1)の方が TMD の付加減衰効果が高い。TMD1 の最終的な power flow 值は(1)の場合が 0.1632 ，(2)の場合が -0.6493 である。

(43)式の 2 個の TMD の付加減衰は $\mathrm{m}_{\mathrm{T} 1} \int \dot{y}_{1} \dot{x}_{5} d t, \mathrm{~m}_{\mathrm{T} 2} \int \ddot{y}_{2} \dot{x}_{5} \mathrm{dt}$ で表さ れ, 2 個の TMD の相対加速度と主振動系の速度の積の時間積分とな る。Fig.25に TMD の同調比が(1)と(2)の場合における 2 個の TMD の 相対加速度, 主振動系の速度の時刻歴応答を比較する。図中には主振 動系の速度が正または負となる時間領域も示す。(1)の場合は最初に主 振動系の応答速度が 0 となる $\mathrm{t}=0.30 \mathrm{~s}$ 以降は TMD1, TMD2 の相対加 速度と主振動系の速度がほぼ同じ位相で振動している。一方, (2)の場
合は TMD1 が時刻歴全体に亘って主振動系と TMD2 のほぼ逆位相で 振動している。1 次モードの応答が生じないことは(1)と(2)で共通であ るが，4．２節で述べた固有べクトルの位相差の違いが時刻歴におけ る応答性状の違いとなって表れ, 結果的に(1)の場合の方が TMD の初 期変位の大きさが小さいにも係らず，2 個の TMD による power flow の合計值が大きく，制振効果が高くなっていると考えられる。

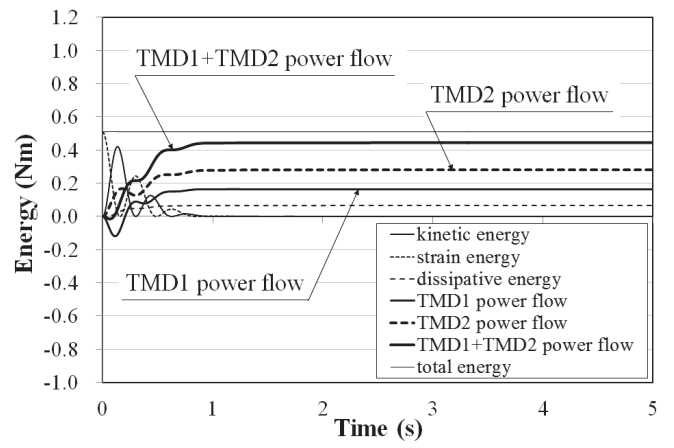

(a) Tuning ratios: (1) $\gamma_{1}=1.2, \gamma_{2}=0.8$

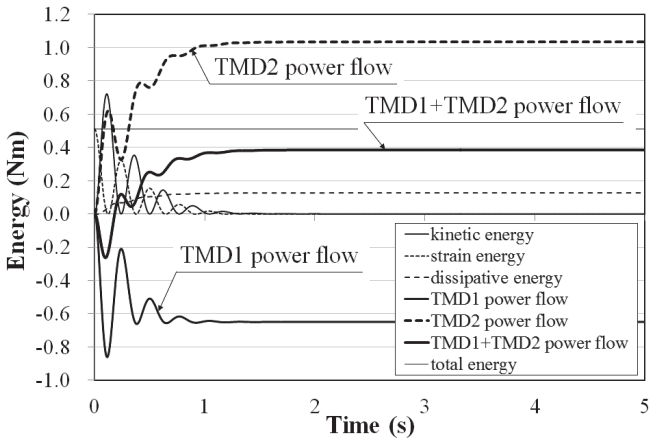

(b) Tuning ratios: (2) $\gamma_{1}=1.2, \gamma_{2}=1.1$

Fig. 24 Time histories of two TMDs power flow

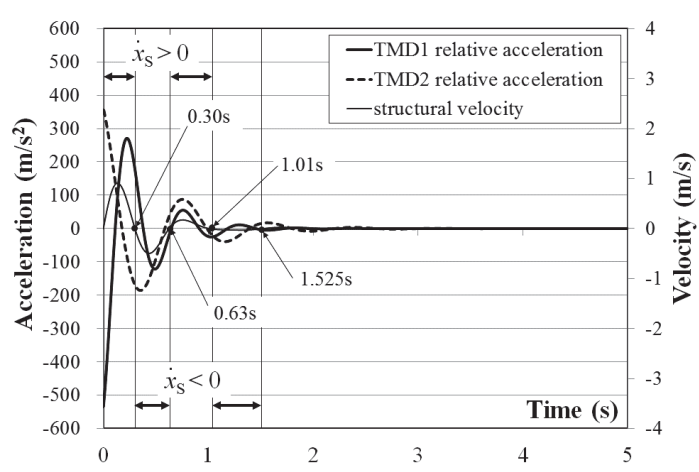

(a) Tuning ratios: (1) $\gamma_{1}=1.2, \gamma_{2}=0.8$

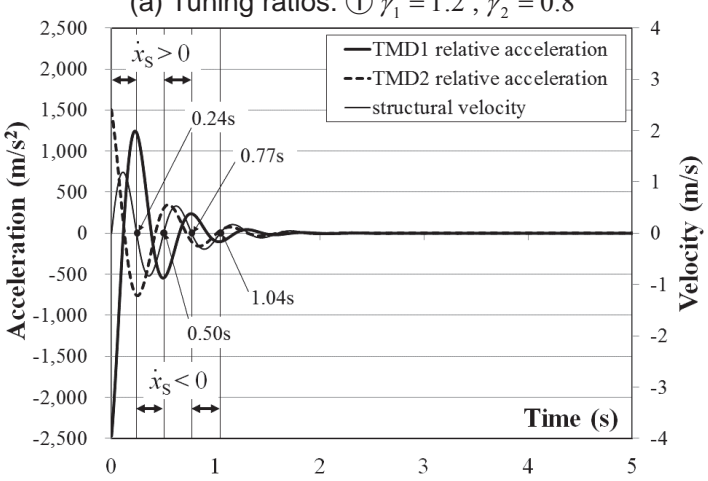

(b) Tuning ratios: (2) $\gamma_{1}=1.2, \gamma_{2}=1.1$

Fig. 25 Comparison of time history responses 


\section{6. まとめ}

本論文では, 初期変位の無い通常の TMD では不可能な高い減衰を 構造物に与えることが可能となる初期変位付与型 TMD について, 地 震動を受けた建築構造における応答制御効果を検討する前段階とし て，自由振動を対象に 3 自由度系の基本的なモデルを用い，2 個の TMD の同調比の設定が制振効果に与える影響を考察した。

本論文の結論を以下の 1）～3）にまとめる。

1) 2 個の TMD の同調比の設定により, 1 次モードの応答を消去する ために必要な TMD 初期変位の大きさと主振動系の応答の大きさが異 なる。TMD 初期変位の大きさと主振動系の応答の大きさには相関が あり，2 個の TMD の同調比がともに 1 より小さいかともに 1 より大 きい場合は，初期変位による TMD の歪みエネルギーと振動応答時間 における歪みエネルギーの平均值が非常に大きくなることが分かっ た。

2) 初期条件を複素平面上で固有モードベクトルに分解し，1）の検 討の結果得られた 1 次モードの応答を消去する TMD 初期変位の大き さと主振動系の応答の大きさに相関がある理由を明らかにした。さら に，TMD の同調比の設定により TMD と主振動系の位相差が変化す る結果， 2 個の TMD の同調比がともに 1 より小さいかともに 1 より 大きい場合は TMD 初期変位と主振動系の応答が非常に大きくなるこ とが分かった。

3 ）初期変位付与型 TMD の制振効果および同調比の設定の違いが主 振動系の応答に与える影響について, TMD による付加減衰効果を表 すエネルギー指標である TMD power flow を用いて考察した。その結

果, 2 個の TMD の同調比がともに 1 より大きい場合は, 初期変位が 大きいにも係らず， 1 個の TMD の power flow 值が時刻歴全体で負の 值となり付加減衰の効率が劣ることが分かった。

今後は実際の建築構造モデルを用い, 制振効果の向上とともに, 初 期変位の大きさを小さくするための手法の提案, 及び初期変位の大き さから見た本手法の適用限界についても検討を進める予定である。

謝辞

本研究は, 平成 28 年度科学研究費補助金基盤研究 (C)「空間構造 の地震応答制御のための複数 TMD を用いた設計法の高度化」による ものである。また, 日本大学名誉教授の新宮清志先生からは研究を進 める上での貴重なご意見をいただきました。ここに謝意を表します。

\section{参考文献}

1) Seto, K.: Dynamic Vibration Absorber and its Application, Corona, 2010 (in Japanese)

背戸一登: 動吸振器とその応用, コロナ社, 2010

2) Kaynia, A.M., Veneziano, D. and Biggs, J.M.: Seismic Effectiveness of Tuned Mass Dampers, Journal of Structural Engineering, ASCE, Vol.107, ST8, pp. 1465-1484, 1981.8

3) Kobori, T.: Seishin-kouzou (Seismic Response Controlled Structure), Kajima, 1993 (in Japanese)

小堀鐸二: 制震構造一理論と実際一, 鹿島出版会, 1993

4) Yoshinaka, S. and Taniguchi, Y.: Proposal of Design Formulas of Tuned Mass Dampers with Initial Displacement to Control Impulse Response Focusing on Vibration Modes, Journal of Structural and Construction Engineering (Transactions of AIJ), Vol.78, No.688, pp. 1071-1079, 2013. 6 (in Japanese)

吉中進, 谷口与史也：振動モードに着目したインパルス応答制御のための初 期変位付与型 TMD 設計式の提案, 日本建築学会構造系論文集, 第 78 巻, 第 688 号, pp. 1071-1079, 2013. 6

5) Abe, M. and Igusa, T.: Semi-Active Dynamic Vibration Absorbers for Controlling Transient Response, Journal of Sound and Vibration, Vol.198 (5), pp. 547-569, 1996. 12
6) Yoshinaka, S. and Taniguchi, Y.: A Study on Conditions to Release Initial Displacement for Tuned Mass Dampers with Initial Displacement, Journal of Structural and Construction Engineering (Transactions of AIJ), Vol.79, No.703, pp. 1247-1257, 2014. 9 (in Japanese)

吉中進, 谷口与史也: 初期変位付与型 TMD $の$ 初期変位解放条件に関寸る考察, 日本建築学会構造系論文集, 第 79 巻, 第 703 号, pp. 1247-1258, 2014. 9

7) Mitsufuji, T., Yoshinaka, S. and Taniguchi, Y.: Study on Vibration Control Using Tuned Mass Damper with Initial Displacement for Arch Model, AIJ Kinki Chapter Research Meeting, No.54, pp. 249-252, 2014. 6 (in Japanese) 光藤龍郎, 吉中進, 谷口与史也: アーチモデルにおける初期変位付与型 TMD による振動制御に関する研究, 日本建築学会近畿支部研究報告集, 第 54 号, pp. 249-252, 2014. 6

8) Yoshinaka, S., Taniguchi, Y. and Yamakawa, M.: Impact Testing of an Arch Model Using Tuned Mass Dampers with Initial Displacement, Journal of Structural and Construction Engineering (Transactions of AIJ), Vol.81, No.722, pp. 735-745, 2016. 4 (in Japanese) 吉中進，谷口与史也，山川誠：初期変位付与型 TMD を設置したアーチモデル の打撃試験, 日本建築学会構造系論文集, 第 81 巻, 第 722 号, pp. 735-745, 2016. 4

9) Yoshinaka, S. and Taniguchi, Y.: Optimal Initial Displacement and Control Effecting Time of Tuned Mass Dampers with Initial Displacement Subjected to Harmonic Base Excitations, AIJ Kinki Chapter Research Meeting, No.53, pp. 521-524, 2013. 6 (in Japanese)

吉中進, 谷口与史也: 調和地動加振を受けたときの初期変位付与型TMD $の$ 最 適初期変位と制振効果時間, 日本建築学会近畿支部研究報告集, 第53号・構 造系, pp. 521-524, 2013. 6

10) Yoshinaka, S., Taniguchi, Y. and Yamakawa, M.: A Study on Control Effect of Tuned Mass Dampers with Initial Displacement under Earthquake Loading, Summaries of Technical Papers of Annual Meeting Architectural Institute of Japan, Structures-1, pp. 665-666, 2015. 9 (in Japanese) 吉中進, 谷口与史也, 山川誠: 初期変位付与型TMDの地震力に対する制振効 果に関する一考察, 日本建築学会大会学術講演梗概集, 構造 I, pp. 665-666, 2015. 9

11)Yamaguchi, H.: Damping of Transient Vibration by a Dynamic Absorber, Transactions of the JSME, Vol.54, No.499, pp. 561-568, 1988. 3(in Japanese)

山口秀谷: 動吸振器による過渡振動の減衰, 日本機械学会論文集, 第54巻, 第55号, pp.561-568, 1988. 3

12) Chopra, A.K.: Dynamics of Structures, Theory and Applications to Earthquake Engineering, Fourth Edition, Chap.14: Analysis of Nonclassically Damped Linear Systems, Prentice Hall, 2011

13) Nagamatsu, A.: Introduction to Modal Analysis, Chap.3.1.5, Corona, 1993 (in Japanese) 長松昭男: モード解析入門, 3.1.5 固有モードの直交性，コロナ社, 1993

14) Soong, T.T. and Dargush,G.F.: Passive Energy Dissipation Systems in Structural Engineering, John Wiley \& Sons, 1997

15)Kozuru, K., Yoshinaka, S. and Taniguchi, Y.: Control Effect of Tuned Mass Dampers with Initial Displacement for Free Vibration Part1: The Effect of Plural Number and Tuning Ratios of Tuned Mass Dampers with Initial Displacement on Impulse Response, Summaries of Technical Papers of Annual Meeting Architectural Institute of Japan, Structures-2, pp. 197198, 2016. 8 (in Japanese)

小鶴桂太，吉中進，谷口与史也：自由振動における初期変位付与型 TMD の 制振効果に関する研究 その 1 複数の初期変位付与型 TMD の個数と同調比 がインパルス応答へ与える影響, 日本建築学会大会学術講演梗概集, 構造 II, pp. 197-198, 2016. 8

16) Yoshinaka, S. and Taniguchi, Y.: Control Effect of Tuned Mass Dampers with Initial Displacement for Free Vibration Part2: Evaluation by TMD Power Flow, Summaries of Technical Papers of Annual Meeting Architectural Institute of Japan, Structures-2, pp. 199-200, 2016. 8 (in Japanese)

吉中進, 谷口与史也: 自由振動における初期変位付与型 TMD の制振効果に 関する研究 その 2 TMD power flow による制振効果の評価と解の存在条件 に関する考察, 日本建築学会大会学術講演梗概集, 構造 II, pp. 199-200, 2016. 8 


\title{
SETTINGS OF TUNING RATIOS OF TUNED MASS DAMPERS WITH INITIAL DISPLACEMENT
}

\author{
Susumu YOSHINAKA* ${ }^{*}$ Keita KOZURU ${ }^{* *}$ and Yoshiya TANIGUCHI ${ }^{* * *}$ \\ * Assoc. Prof., Urban Engineering, Faculty of Engineering, Osaka City University, Dr. Eng. \\ ** Grad. Student, Faculty of Engineering, Osaka City University, M. Eng. \\ *** Prof., Urban Engineering, Faculty of Engineering, Osaka City University, Dr. Eng.
}

A TMD (Tuned Mass Damper) is a passive-type control device that consists of a small mass, a spring and a damper. And it absorbs the oscillation energy of structures as the kinetic energy of its mass and disperses it via its damper. The TMD shows high control performance for harmonic responses. On the other hand, the TMD has limited capacity to suppress transient responses. The reason is that there is some time delay before the TMD becomes fully effective because they are initially at rest.

Thus, to control the transient response more effectively, we propose TMDs with initial displacement, that is, dampers whose springs are stretched until the release moment.

In our previous study, we focused on the considerably high modal damping ratio of the second mode compared to the first mode based on the relationship between the TMD damping ratio and the modal damping ratio of a two-degree-offreedom model. And we proposed the design formulas for the optimal tuning and damping ratios and the initial displacement to attain high control performance under impulse loading. The proposed design formulas are based on the principle that by giving the specific TMD initial displacement under the specific structural initial condition the structural response of the first mode with low modal damping is eliminated while the structural response of the second mode with high modal damping is only oscillated. But the physical meaning of the design formula for TMD initial displacement is not clear because it is an approximate solution based on the perturbation method.

Then, we formulated the equation for initial conditions to release TMD initial displacement from the theoretical free vibration solution and showed its physical meaning clearly. We studied about TMD initial displacement and structural conditions to release initial displacement using the complex plane, and we showed that the initial structural condition to oscillate only the second mode was limited to a neighborhood of $\dot{x}_{0} \neq 0, x_{0}=0$. On the other hand, we proved that, by dividing one TMD into plural TMDs that have different natural frequencies, any initial structural conditions to release TMDs became possible.

In this paper, firstly, we analytically study the effect of different settings of two TMDs tuning ratios on TMD initial displacements to eliminate the first modal response with the lowest modal damping and structural responses for free vibration using a basic three-degree-of-freedom model. Next, we decompose the initial condition to modal eigenvectors on the complex plane and study the interrelationship between each initial condition of a main mass and two TMDs. Then, we show the reason why different settings of TMDs tuning ratios affect the TMD initial displacements to eliminate the first modal response and the structural responses. Finally, by using the energy indicator "TMD power flow" that shows an additional TMD damping effect proposed by Soong, T.T. and Dargush, G.F., we study the control performance of TMDs with different tuning ratios condition. 